\title{
Charting the Future
}

Editor's note: I have asked a number of people from different facets of oceanography to reflect on the greatest opportumities and challenges facing occan sciences in the final decade of this century. Here we present four essavs highlighting individual outlooks for the $1990 \mathrm{~s}$.

\section{OUTLOOK FOR THE 1990s}

\author{
By D. James Baker
}

$\mathrm{T}$

HEPAST decade was one of exciting discoveries and a new recognition of the importance of the ocean in global environmental change. In fact, the latter part of the decade was marked by an enormous effort in planning for new cooperative global studies that hold the promise of answering major questions about the ocean as part of the Earth system. But will the new programs that have been planned actually take place as proposed?

The good news is that global change programs are receiving high priority in the funding plans of many nations. Perhaps the best example comes from the UK, where oceanographers were recently pleased to hear the Prime Minister announce to the United Nations that Britain would take a leadership role in global change and actually mentioned an ocean program, the World Ocean Circulation Experiment. by name. The bad news is that there are more programs being planned than can be funded adequately by the arrangements used in the past. Even if programs are stretched out and sequenced. it is clear that we need new resources and facilities in the system.

In a recent article in The Economist. management guru Peter Drucker noted that the few precedents of successful common international actions include suppression of the slave trade. outlawing piracy, and the Red Cross. He could have added oceanography, which has always been global and which has demonstrated the value of international cooperation for the effective sharing of resources. As the 1990s begin, we are seeing an acceleration of the ability of many countries and groups of countries around the world to contribute to support of ocean science.

Just to mention two examples: in Japan and the smaller Asian "tigers" that are now following it

D. James Baker, Joint Oceanographic Institutions. Inc., 1755 Massachusetts Avenue, N.W., Washington. D.C. 20036.

economically, the growing prosperity is allowing a greater percentage of funds for science programs. Ocean science has been one of the beneficiaries, particularly for ship facilities. The Japanese oceanographic community has just supported the development of a new research vessel now completing a world-circling expedition, a $6500 \mathrm{~m}$ deep-diving submersible. and is considering a large new drilling vessel to be completed by the year 2000 . Japan is also undertaking major initiatives in marine biotechnology. In the USSR, perestroika is permitting a frank exchange of views with the outside community that could lead to major new cooperative efforts. An expanded use of Soviet scientific and ship resources in the various newly-proposed international programs could provide much needed help.

With the planning for the Europe of 1992 has come a new sense of unity and the creation of new organizations to facilitate cross-frontier cooperation in research and development. Such new organizations are now being considered as possible vehicles for developing new resources in oceanography, including the funding of a large new dynamicallypositioned research vessel, the Nereis project, aimed at serving the needs of a broad interdisciplinary ocean science community from paleoclimate to benthic biology.

The emergence of new funding from growing economies and the opening up of new cooperative arrangements offer hope that some of the limitations we face may be removed. As we look to the 1990s, it is essential that all planning for cooperative ocean programs look to new international developments and use these to the fullest to identify the resources that are required.

\section{Biological Oceanography: Past, Present and Future}

\author{
By John J. Cullen
}

LIKE SEASICKNESS, a lack of data has plagued biological oceanographers since the first nets, bottles and grabs went over the sides of sailing vessels. Observations were hard to get, and biologists made the best of them, using intuition, generalization and extrapolation to relate what they measured (e.g., concentration of chlorophyll, secchi depth, contents of net tows and grab samples) to what they wanted to know (distributions and productivity of phytoplankton, spatial patterns and activities of zooplankton and fish, benthic ecological interactions). The ulti-

John J. Cullen. Bigelow Laboratory for Ocean Sciences. McKown Point. West Boothbay Harbor, ME 04575 . 
mate objective was to describe what determines the distributions and activities of organisms in the sea.

Times have changed. Even though nets, bottles, grabs and an occasional meal still go over the side during cruises throughout the world, large amounts of data are being obtained with in situ and remote sensors. Optical instruments measure properties of bacteria and phytoplankton, acoustic devices survey zooplankton and fish, and the benthos is observed with remote video. Sensors are placed in orbit. flown in airplanes or installed in long-term moorings, and huge quantities of data are obtained with unprecedented resolution on scales that are completely inaccessible to ships. The problem of undersampling is being buried in magnetic media.

Yet, the thrust of biological oceanography is essentially unchanged: we still use intuition, generalization and extrapolation to relate what we measure (e.g., ocean color, chlorophyll fluorescence, beam attenuation, acoustic backscatter, distributions of benthic animals in relation to bottom topography) to what we want to know (distributions and productivity of phytoplankton, spatial patterns and activities of zooplankton and fish, benthic ecological interactions). The scope of the discipline has been broadened by conceptual and technological advances to include the role of marine life in global biogeochemical cycles and climate change.

Biological oceanography is interdisciplinary. Taxonomy is essential, because even though species can be grouped into broad categories, taxonomic differences can have profound ecological and biogeochemical consequences. Physiological studies are needed to relate what can be measured in the field to essential information that can be observed only in the lab. Molecular biology is a new and powerful link between the lab and field. Physical forcing and nutrient supply ultimately determine biotic response. and the biota influence physics as well as chemistry, so physical and chemical oceanography are integral to biological oceanographic research. Small plankton strongly affect light transmission in the sea, so biological and optical oceanography are closely linked. Atmospheric science and global biogeochemistry are now included. because plankton influence global climate as agents of $\mathrm{CO}$, flux and are sources of atmospheric sulfur compounds implicated in cloud formation. The challenge of the 1990 s is to establish common ground between these disciplines: not only mutual understanding and appreciation, but also the practical solutions for effective cooperative research on problems of great complexity.

One solution is Big Science, an approach which brings individual talents to bear on a central focus. Big Science is good because it does things no individual can do alone. But because it is centralized and expensive, it threatens independent efforts in basic science. which have formed the foundation of biological oceanography. We must ensure that Big Science serves as the roof under which we meet rather than the temple in which we must worship.

\section{Major Challenges in Chemical Oceanography}

By Ellen R.M. Druffel

$\mathrm{M}$ AJOR CHALLENGES are facing ocean science, most of them interdisciplinary, and most of them requiring the input and participation of chemical oceanographers to solve. Many of the important agenda items involve the cycling of bioactive elements, most notably carbon. For example, where in the oceans and by what process(es) is oxygen utilized (and hence organic matter oxidized)? Dissolved organic matter in the oceans $(<1 \mu \mathrm{m}$ effective diameter) appears now to play an important role in this process, but what is it, where does it come from and how is it transformed/adsorbed/transported/utilized? Is it concentration changing with time? In order to adequately understand organic matter cycling, we need to earmark the important photochemical and biochemical controls on organic matter and other chemical species in the euphotic zone. We also are in need of more accurate assessments of the contributions of hydrothermal, sediment, riverine and atmospheric inputs to the oceanic organic matter pool. Other vexing problems are the relation between fluxes measured by sediment traps and the corresponding true fluxes in the ocean: how exactly do trace metals such as iron affect primary production; and are there unequivocal measures of new production?

Large technological breakthroughs need to be made in the next few years. There is a need for longterm automated acquisition and transmission of crucial chemical data using moored arrays deployed at remote areas of the ocean, and short term synoptic in situ analyses of biologically important chemical properties (i.e., nutrients) throughout the water column.

Tracer distributions, powerful tools for determining the subtle (and not so subtle) aspects of ocean circulation, will be pursued in the next decade with an emphasis on new techniques designed to measure ${ }^{1+} \mathrm{C},{ }^{3} \mathrm{H},{ }^{3} \mathrm{He}$ and other tracers in small volume water samples. A large amount of effort will be needed for the interpretation of data from remote sensing observations with emphasis on the types of chemical information that can be abstracted from these signals. Information on how chemical exchange processes in the upper ocean and at the air-sea interface are affected by elevated sea states needs to be gathered using stable platforms, i.e.. SWATH (Small Waterplane Area Twin Hull) vessels. Proxy records of past climate change will give us a window into future changes expected due to anthropogenic im-

Ellen R.M. Druffel. Woods Hole Oceanographic Institution. Woods Hole. MA 02543.
Wo

Big Science serves as

the roof under which we

meet rather than the

temple in which we

must worship. 
Mor ore than ever we need people who will sacrifice some of their own science for the good of the field. pacts on the environment. Time histories of various chemical and isotopic parameters from unaltered integrators (sediments, corals, shells, ice cores) need to be reconstructed on a much wider spatial scale. The deep-sea must be emphasized as a major focus for this reconstruction, as changes in this water mass may be driving long term climatic fluctuations.

Thus, we now find ourselves in the midst of a transition, from observing the oceans with the thought of steady-state firmly imbedded in our minds, to dealing with the reality of long (1-100y) and short $(<$ 1 y) time scale changes in most of the processes we study. It is imperative that new sources of funding be secured in the next decade to ensure maximum progress on these fronts as well as to encourage bright students into joining our efforts. Implementation of large programs appear to be a sine qua non for obtaining new sources of funds, but this must not be done at the expense of core funding for innovative and risky proposals, which are often the springboard for new and exciting fields of science.

\section{Physical OCEANOGRaPhy IN THE 1990s}

\section{By Donald B. Olson}

IN ORDER to consider what the new decade might bring in physical oceanography, it is worthwhile to reflect on where the last ten years have brought us. In 1979 the last experiments of the International Decade of Ocean Exploration (IDOE) were going into the water. the last of the major Geosecs lines had been completed, and the Polymode experiment was entering its analysis stage. The year before had seen Seasat soar and die, the first description of acoustic tomography, and the publication of one of the most ambitious attempts to understand the ocean circulation with a high resolution model to that date. The end of the 1980s saw modeling attacking ever more realistic domains, both in terms of resolution and scope of coverage. It is fair to say that the application of tomography is still in its infancy. During its short lifetime, Seasat collected enough data to keep the community busy for half the decade. The use of satellite remote sensing of the ocean has blossomed, but overall satellite oceanography has suffered with the rest of the U.S. national space program. A bright note was Geosat's mission, which culminated five days into the new decade. Perhaps the worst news in the 1980 s was the turmoil over replacing the Big Science programs. Although there has been an incredible amount of planning activity, the end of the decade saw most of the plans to renew the systematic

Donald Olson, Rosenstiel School of Marine and Atmospheric Sciences, University of Miami. 4600 Rickenbacker Cswy. Miami, FL 33149. investigation of the world's ocean confined mostly to paper.

It is the last point which bears most heavily on where the field will be at the turn of the century. Ocean science is fast approaching its maturity and must work to become an increasingly more responsible member of the science community. This will probably involve gains and losses. On the plus side, one hopes the funding climate for ocean scientists will evolve into less of a hand-to-mouth situation, with growth of more "hard-money" salary coverage. The budget deficits in the US and the pressing needs in other areas, however, are probably going to slow the pace of field efforts and make oceanography more international than it has been since the beginning of our century. A mature approach to funding is probably the single most important lesson that we must take to heart. Although this runs against Henry Stommel's sage advice to the individual scientist (Occanography. November 1989), more than ever we need people who will sacrifice some of their own science for the good of the field. Without excellent scientists on panels, as program managers, and in a wide variety of public relations efforts, we will not be equipped to adequately secure the resources needed for understanding and using the ocean environment. It is also evident that much time will be spent assigning tough long-term priorities if the discipline is going to maintain reasonably modern laboratory facilities, up-todate computation capabilities, and such high-cost items as satellites and ships.

A growing public concern about the well-being of the earth and its climate system suggests that the plans of the late $1980 \mathrm{~s}$ will go forward, albeit at a lesser rate than originally envisioned. The intensive hydrographic effort which must be a major part of such programs should lead to major improvements in the techniques for making fast. high-quality measurements through the water column. New satellites will slowly begin to produce long-term, continuous data sets on ocean surface conditions. We would like to see major advances in the monitoring of air-sea fluxes, but past efforts imply that the gain by 2000 will be hard won. "Surface-truthing" the satellite systems and the effort to make better flux measurements may renew efforts to understand small scale surface processes such as wind waves and turbulence.

The turn of the century should see new generations of coupled atmosphere-ocean models. On the ocean side are needed new efforts to develop improved subgrid physics to bring the ocean dynamics up to the atmospheric standard. To encourage theoretical developments, we hope to see the 40th Geophysical Fluid Dynamics summer program in 1997. It is hard to predict what new challenges will face the theoretician, but one sincerely hopes that a revitalized national education system will be producing well-trained young minds anxious to challenge the old guard.

[ Please Turn To Page 64 ] 
as alleging "that many scientists concerned about pollution, ozone depletion and global warming are motivated more by pecuniary interests than by altruistic desires to advance the common good." This allegation. the editorial says, "may be dismissed as extremist or irrational. unworthy of reaction." The tone of the editorial is that the scientist is above such suspicion.

If the Chronicle article does suggest that greenhouse scientists are motivated by pecuniary rather than altruistic interests, then it is, of course, wrong. But its error is not because scientists are morally superior, but because it twice misunderstands the motivation of scientists: few, if any, world-class scientists entered science to get rich, and relatively few entered the physical sciences to advance the common good.
A subtle discussion of their actual motivation is in the same issue of Oceanography (Nov. 89. H. Stommel, "Why We are Oceanographers"). Scientists become scientists to discover things about the world around us. The currency of science is not dollars, but fame for discovery, and that fame increases with the unexpectedness and generality of the discovery. In seeking fame, scientists are not morally superior to nonscientists. There are many examples of how the desire for fame corrupted a scientist's actions, from the subconscious rejection of non-confirming data to the brutal discrediting of rival theories.

Predictions of the effects of greenhouse warming are part of the scientific fame of those making the predictions. When the predictors seek to influence public policy with advice based on their predictions, a citizen is only being prudent in requiring skeptical review.

Cyril Galvin. Principal Coastal Engineer Box 623. Springfield. Virginia 22150

My comments about the Chronicle article were prompted mostly by its summary statement. "we are being peddled protection from non-existent hazards." To me, this seems an extreme and irrational view, given the mounting evidence for ozone depletion and global warming and the environmental hazards they portend. Far from being exempt from public scrutiny, scientists face an added obligation to sift arailable evidence and interpret it responsibly for a critical public. $-D A B \square$

\section{Convergent Shelf Flow at Cape Mendocino}

[ Continled from Page 11 ]

\author{
Magnell, B.A.. C.D. Winant. N.A. Bray, J.F. \\ Borchardt. C.L. Greengrove, C.E. Dor- \\ man. R.L. Bernstein. 1989: The Northern \\ California coastal Circulation Study: \\ Results of the Pilot Program. Prepared for \\ Department of Interior, Minerals Man- \\ agement Service. EG\&G WASC Oceano- \\ graphic Services Report No. NCCCS-89-2. \\ Waltham, Massachusetts. $270 \mathrm{pp}$. \\ Magnell, B.A., J.F. Borchardt, C.L. Greengrove, J.B. \\ Andrews. C.D. Winant, N.A. Bray. C.E. Dor- \\ man, and R.L. Bernstein, 1988: Northern
}

California coustal Circulation Study Data Report No. 1: Pilot Measurement Program, March-August 1987. Prepared for Department of Interior, Minerals Management Service. EG\&G WASC Oceanographic Services Report No. NCCCS-89-9, Waltham. Massachuseuts. $268 \mathrm{pp}$.

Rosenfeld, L.K. and R.C. Beardsley, 1987: Barotropic Semidiurnal Tidal Currents off Northem California During CODE. J. Geophys Res.. 92(C2). 1721-1732.
Winant, C.D., R.C. Beardsley, and R.E. Davis, 1987: Moored Wind. Temperature, and Current $\mathrm{Ob}-$ servations made During Coastal Ocean Dynamics Experiments 1 and 2 over the Northern California Continental Shelf and Upper Slope. J. Geophys. Res., 92(C2). 1569-1604.

Winant, C.D.. C.E. Dorman, C.A. Friehe, and R.C. Beardsley, 1989: The Marine Layer off Northem Californa: An example of supercritical channel flow. $J$. Atmos. Sci.. 45, 3588-3605. $\square$

\section{Physical Oceanography in the 1990s}

[ Continued from Page 52 ]

In the late $1980 \mathrm{~s}$, as a cure for perceived lagging productivity in science. the federal government began to push multi- and interdisciplinary research. By tradition and its very nature, ocean science has always been at least multidisciplinary and in many cases interdisciplinary. The hard questions concerning global climate change in the next decade will require advances in areas of common need, such as moored technology for chemistry and biology, modeling as an integrator of fields, and a fuller appreciation of the wealth of intellectual problems in ocean science.

New tools for measuring currents and improved models capable of handling the messy combination of processes at work in the coastal ocean may make the 1990s the decade of the coastal oceanographer. Again. some of the growth in this area will be fed by a community more closely tied to socie- tal needs in the coastal domain. Finally, to match the observations from space. the hydrographic efforts, and the models, it is possible to forsee a global in situ ocean measurement network based on very-longterm site moorings, global drifter and float networks, and even perhaps the first "Slocums," as Stommel suggested. The latter will bring ocean science closer to meteorology, but not to the point, one hopes, where scientists no longer go to sea. 